Berkala Ilmu Perpustakaan dan Informasi, Vol. 13, No. 2, Desember 2017, Hal. 178-190 DOI: $10.22146 /$ bip.27224

ISSN 1693-7740 (Print), ISSN 2477-0361 (Online)

Tersedia online di https://jurnal.ugm.ac.id/bip

\title{
MENGURANGI KECEMASAN PEMUSTAKA DALAM PROSES PENELUSURAN INFORMASI MELALUI LAYANAN VIRTUAL REFERENS DI PERPUSTAKAAN PERGURUAN TINGGI
}

\author{
Moh Very Setiawan ${ }^{1}$ \\ ${ }^{1}$ Manajemen Informasi dan Perpustakaan Sekolah Pascasarjana UGM \\ e-mail:mohamad.very13@gmail.com
}

Naskah diterima: 3 Agustus 2017, direvisi: 25 September 2017, disetujui: 2 Oktober 2017

\begin{abstract}
ABSTRAK
Setiap orang memiliki kecamasan yang berbeda-beda dalam mencari dan mengelola sumber informasi. Hal ini terkait perbedaan kemampuan dan kepercayaan diri masing-masing orang. Artikel ini bertujuan untuk mengkaji bagaimana layanan virtual reference yang disediakan oleh perpustakaan perguruan tinggi yang dapat membantu mengurangi kecemasan kebutuhan informasi pemustaka. Kajian artikel ini dilakukan secara deskriptif kualitatif dengan cara mengkaji beberapa literatur terkait dengan kegiatan penelusuran informasi dan bentuk-bentuk layanan referens yang dapat diterapkan di perpustakaan perguruan tinggi. Hasil artikel ini menjelaskan bahwa, untuk membantu mengurangi kecemasan kebutuhan informasi para pemustaka dalam penelusuran informasi, diantaranya dapat dilakukan dengan menyediakan layanan virtual referens. Bentuk layanan virtual referens yang dapat dilakukan pada perpustakaan perguruan tinggi seperti: layanan research consultation seperti yang dilakukan oleh perpustakaan Singapore Management University, live chat dan penyediaan informasi dalam bentuk video yang dilakukan oleh perpustakaan University of Kentucky, research guide yang dilakukan oleh perpustakaan Harvard University, layanan ask librarian, layanan research assistant dan lain sebagainya.
\end{abstract}

Kata Kunci: Layanan virtual referens; Kecemasan penelusuran informasi; Perpustakaan perguruan tinggi

\begin{abstract}
Everyone has different anxiety in finding and managing information sources, based on their . ability and confidence. This article aims to examine how virtual reference services are provided by academic libraries help reducing the library user anxiety. The study used descriptive qualitative approach by reviewing some literature related to information and reference services in academic libraries. The results show thatvirtual reference services play a significant role to help reduce the users' anxiety in satisfying their information needs. The virtual reference service appied in academic librariesincluding research consultation services as conducted by Singapore Management University library, live chat and provision of information in the form of a video as conducted by University of Kentucky library, a research guide as conducted by Harvard University library, and "ask librarian"..
\end{abstract}

Keywords: Virtual reference service; Information seeking anxiety; College library 


\section{A. PENDAHULUAN}

Setiap individu memiliki kebutuhan informasi yang berbeda. Kebutuhan informasi ini merupakan suatu keadaan yang terjadi dalam struktur kognisi seseorang, ketika terjadi kekosongan informasi atau kurangnya pengetahuan yang dimiliki. Adanya kekosongan dan kebutuhan pemenuhan informasi ini mendorong seseorang untuk berinteraksi atau berkomunikasi dengan berbagai sumber informasi, agar dapat memperoleh informasi yang sesuai dengan kebutuhannya (Yusuf dan Priyo Subakti, 2010). Dalam pencarian informasi, seringkali seseorang mengalami kebingungan yang diakibatkan oleh banyak faktor, diantaranya yaitu karena banyaknya informasi yang diperoleh. Kebingungan ini terjadi karena seseorang harus memilih dan menentukan mana informasi yang paling tepat dan dapat memenuhi kebutuhan mereka (Prabha, dkk., 2007).

Selain mengalami kebingungan untuk memilih informasi yang tepat, seringkali seseorang yang memiliki informasi berlebih juga memiliki kekhawatiran tidak dapat mengelola informasi yang dimiliki (Afifi dan Weiner, 2009). Hal ini yang menjadi salah satu faktor yang dapat memunculkan pertimbangan bagi seseorang, untuk memutuskan apakah dia akan melakukan pencarian informasi ulang atau mengakhiri pencarian (Afifi dan Weiner, 2009). Atas dasar ini terkadang seseorang memutuskan untuk tidak melakukan pencarian informasi ulang dan merasa cukup dengan informasi yang dimiliki.

Pada perguruan tinggi, perpustakaan dapat membantu mengurangi ketidakpastian kebutuhan informasi para pemustaka dengan menyediakan informasi yang tepat, untuk menunjang kegiatan pendidikan dan penelitian. Beberapa koleksi tersebut seperti adanya literatur-literatur pendukung pendidikan dan penelitian, majalah-majalah ilmiah, dan koleksi lain dalam bentuk tercetak ataupun elektronik (Standar Nasional Perpustakaan Perguruan Tinggi, 2009). Sumber-sumber informasi tersebut merupakan sumber informasi terseleksi yang ada di perpustakaan.
Selain menyediakan berbagai sumber informasi, untuk mengurangi ketidakpastian kebutuhan informasi pemustaka perpustakaan juga dapat menyediakan beberapa inovasi layanan. Layanan tersebut seperti layanan virtual referens. Pada penelitian yang dilakukan oleh Vohra (2007) menjelaskan bahwa, layanan virtual referens yang disediakan oleh perpustakaan dapat membantu para pemustaka untuk memperoleh berbagai macam informasi secara lebih mudah. Layanan ini dapat berupa layanan digital reference seperti e-mail, web dan real time reference services yang meliputi kegiatan: layanan jawaban agar pemustaka dapat mengajukan pertanyaan, membuat komentar melalui e-mail atau chatting.

Selain Vohra, pada penelitian Kern (2009) menjelaskan bahwa layanan referens yang dapat disediakan oleh perpustakaan seperti collaborative virtual reference yang dilakukan pada beberapa perpustakaan, untuk saling memudahkan para pemustaka memperoleh layanan referens secara cepat. Penelitian Amin dkk (2003) menjelaskan, dalam layanan referens pustakawan juga dapat berperan sebagai asisten penelitian untuk dapat membantu para pemustaka memperoleh sumber informasi yang tepat.

Atas dasar ini penulis tertarik untuk mengkaji bagaimana layanan virtual referens yang dapat disediakan oleh perpustakaan perguruan tinggi, yang dapat membantu mengurangi kecemasan kebutuhan informasi para pemustaka, dalam kegiatan penelusuran informasi.

\section{B. TINJAUAN PUSTAKA}

Banyak artikel dan penelitian yang telah membahas mengenai kecemasan pemustaka dalam kegiatan penelusuran informasi atau layanan referens yang dapat disediakan di perpustakaan. Namun berdasarkan pencarian yang penulis lakukan melalui "google" dan sistem penelusuran "one search" yang disediakan Perpustakaan Nasional Indonesia, belum ditemui artikel atau penelitian yang mengkaji mengenai layanan virtual referens di perpustakaan perguruan tinggi untuk 
mengurangi kecemasan penelusuran informasi pemustaka. Seperti penelitian Erfanmanesh (2016) yang mengkaji bagaimana perbedaan kecemasan seseorang dari segi umur dan gender yang berbeda, dalam kegiatan penelusuran informasi. Penelitian ini dilakukan kepada 375 sampel mahasiswa pascasarjana di sebuah universitas di Kuala Lumpur Malaysia. Penelitian ini menjelaskan bahwa adanya perbedaan secara signifikan pada segi umur mahasiswa dengan kecemasan dalam penelusuran informasi. Sedangkan pada segi gender tidak ditemui adanya perbedaan yang signifikan. Penelitian Orlu (2016) menjelaskan bahwa kecemasan yang dirasakan seseorang dalam kegiatan penelusuran informasi, banyak dipengaruhi oleh faktor emosi masing-masing individu. Atas dasar ini perpustakaan harus menyediakan sebuah sistem informasi yang dapat memaksimalkan emosi positif yang dimiliki seseorang, sehingga sistem yang efektif tersebut dapat berkontribusi untuk meningkatkan kemudahan dalam kegiatan penelusuran informasi.

Pada tema layanan referens, Vohra (2007) yang meneliti mengenai tren layanan referens yang dapat disediakan di perpustakaan di era elektronik menjelaskan bahwa, layanan virtual referens yang disediakan oleh perpustakaan dapat membantu para pemustaka untuk memperoleh berbagai macam informasi secara lebih mudah. Layanan ini dapat berupa layanan digital reference seperti e-mail, web dan real time reference services yang meliputi kegiatan: layanan jawaban agar pemustaka dapat mengajukan pertanyaan, membuat komentar melalui e-mail atau chatting. Pada penelitian Kern (2009) menjelaskan bahwa model lain dari layanan virtual referens yang dapat disediakan oleh perpustakaan seperti menyediakan layanan video conferencing atau video chat yang dapat memfasilitasi pemustaka untuk berhubungan secara langsung dengan pustakawan tanpa harus datang secara fisik. Layanan lain yang dapat disediakan menurut Kern yaitu, layanan collaborative virtual reference yang dapat memberikan layanan refens kepada pemustaka, melalui kerjasama beberapa perpustakaan untuk memenuhi kebutuhan informasi pemustaka secara real time. Selanjutnya penelitian Amin (2003) menjelaskan bahwa, pada layanan referens di perpustakaan perguruan tinggi, pustakawan juga dapat berperan sebagai rekan peneliti atau asisten peneliti. Dengan layanan ini pustakawan dapat membantu pemustaka untuk memperoleh sumber informasi secara tepat. Atas dasar ini pustakawan juga dituntut untuk memiliki kemampuan dalam hal penelitian dan mereka merupakan orang yang ahli dalam spesialisasi subjek keilmuan tertentu. Pada artikel ini akan membahas mengenai bagaimana layanan virtual referens yang dapat disediakan di perpustakaan perguruan tinggi, yang dapat membantu mengurangi kecemasan penelusuran informasi yang dilakukan pemustaka.

Adanya fenomena kecemasan pemustaka dalam penelusuran informasi, menjadikan beberapa pakar tertarik untuk mengkaji permasalahan ini agar dapat memperoleh model-model dan teori yang dapat membantu memahami kecemasan yang dimiliki pemustaka. Diantaranya yaitu Theory of Motivated Information Management (TMIM) yang dijelaskan oleh Afifi dan Weiner (2009). Teori ini menjelaskan mengenai bagaimana seseorang termotivasi untuk mengelola ketidakpastian dalam pencarian informasi. Pada bidang perpustakaan, teori ini dapat membantu para pustakawan dalam melakukan prediksi mengenai apa yang dilakukan pemustaka saat mereka memiliki kecemasan dalam proses pencarian informasi.

Model teori ini menjelaskan bahwa, dalam pencarian informasi yang dilakukan individu, terbagi dalam tiga tahapan. Tahapan tersebut yaitu: a. Tahap Interpretasi, b. Tahap Evaluasi, c. Tahap Pengambilan Keputusan. Pada tahap interpretasi, individu akan menilai ketidakpastian yang dimiliki tentang suatu masalah terkait kebutuhan informasi yang dimiliki. Tahap ini akan mempengaruhi emosi seseorang yang mana emosi ini akan mempengaruhi pada tahap evaluasi. Pada tahap evaluasi, seseorang akan membuat tiga jenis penilaian keberhasilan. Penilaian tersebut yaitu: coping efficacy (keberhasilan dalam mengatasi ketidakpastian), communication efficacy (keberhasilan dalam berkomunikasi) dan target 
efficacy (keberhasilan dalam target). Dari tahap evaluasi ini selanjutnya seseorang akan memasuki tahap pengambilan keputusan dan mereka akan membuat keputusan untuk melakukan pencarian informasi, menghindari informasi, atau merubah pola pikir mereka tentang kebutuhan informasi yang dimiliki. Model dari Afifi dan Weiner (2009) sebagai berikut:

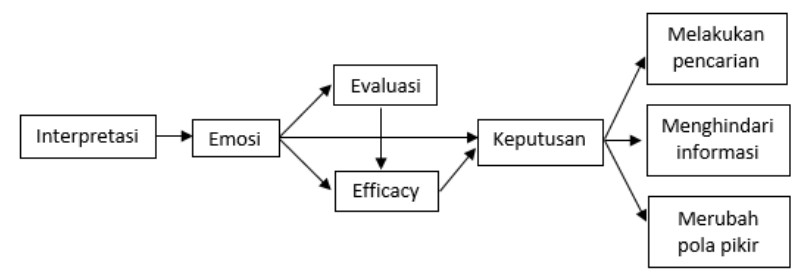

Atas dasar ini, penulis ingin membahas mengenai bagaimana layanan virtual referens yang dapat disediakan di perpustakaan perguruan tinggi yang dapat membantu yang dapat membantu mengurangi kecemasan kebutuhan informasi para pemustaka, dalam kegiatan penelusuran informasi.

\section{METODE PENELITIAN}

Kajian ini menggunakan metode deskriptif kualitatif. Menurut Sulistyo-Basuki penelitian kualitatif merupakan penelitian yang bertujuan untuk memperoleh gambaran mengenai suatu hal yang tidak dapat diukur dengan angka, secara lebih detail (Sulistyo-Basuki, 2010). Sedangkan penelitian deskriptif menurut Ghony dan Fauzan Almanshur yaitu penelitian yang dilakukan dengan cara pegumpulan data berupa kata-kata, gambar atau data lain selain angka (Ghony dan Fauzan Almanshur, 2012:34).

Pada artikel ini mengkaji beberapa literatur yang berkaitan dengan inovasi layanan referens, layanan virtual referens dan kegiatan penelusuran informasi yang dilakukan oleh pemustaka. Pencarian literatur tersebut dilakukan melalui database jurnal yang dilanggan oleh perpustakaan UGM dan melalui artikel open access yang dapat diakses melalui google scholar dan google advance. Literatur yang digunakan yaitu literatur dalam bahasa Indonesia dan Inggris dengan format "pdf".

Dengan metode ini diharapkan penulis dapat memberikan gambaran secara jelas mengenai bagaimana layanan virtual referens yang dapat disediakan oleh perpustakaan perguruan tinggi, dalam membantu mengurangi kecemasan para pemustaka, dalam kegiatan penelusuran informasi.

D. HASIL DAN PEMBAHASAN

1. Penelusuran Informasi dan Kecemasan pemustaka

a. Penelusuran Informasi

Kegiatan penelusuran informasi diawali dengan adanya kebutuhan informasi yang muncul dari dalam diri manusia. Menurut Taylor, hal ini dapat terwujud setelah melalui proses-proses sebagai berikut (Pendit, 2008):

1. Visceral need, yaitu kebutuhan informasi yang belum sungguh-sungguh dikenali sebagai kebutuhan. Hal ini disebut sebagai kebutuhan "tersembunyi" yang seringkali baru muncul setelah ada pengalaman tertentu,

2. Conscious need, yaitu tahap ketika seseorang mulai mereka-reka apa sesungguhnya yang dia butuhkan,

3. Formalized need, yaitu ketika seseorang mulai secara lebih jelas dapat mengenali kebutuhan informasinya. Pada tahap ini seseorang baru dapat menyatakan kebutuhannya kepada orang lain.

4. Compromised need, yaitu ketika seseorang mengubah-ubah rumusan kebutuhannya karena mengantisipasi, atau bereaksi terhadap kondisi tertentu.

Hal yang melatarbelakangi kegiatan penelusuran informasi yang dilakukan setiap orang juga berbeda-beda. Hal ini terkait dengan kepentingan masing-masing individu. Dervin menjelaskan beberapa kepentingan tersebut yaitu:

1. Untuk mendapatkan ide, pengertian, atau gambaran agar dapat melintasi ruang dan waktu,

2. Untuk mendapatkan kemampuan dan keterampilan (skills),

3. Agar termotivasi, dapat dimulai suatu pekerjaan atau mulai belajar, 
4. Agar dapat membuat situasi lebih baik atau lebih tenang,

5. Agar dapat merasa senang, puas, dan rileks (Ati, dkk., 2013).

Setelah kebutuhan informasi muncul dalam diri seseorang, hal selanjutnya yang akan mereka lakukan yaitu melakukan penelusuran informasi. Menurut Ellis proses penelusuran informasi yang dilakukan oleh seseorang berawal dari tahap starting (memulai pencarian) hingga tahap ending (penyelesaian setelah mengumpulkan informasi yang diperoleh) (Orlu, 2016). Pada proses penelusuran informasi ini Kuhlthau berpendapat lain. Tahapan yang dijelaskan Kuhlthau dimulai dari tahap insiasi, yaitu ketika seseorang mulai menyadari kebutuhan informasinya, hingga tahap presentation (presentasi) yaitu tahap pemaparan ketika mereka telah menemukan informasi yang dibutuhkan. Secara lebih detail tahap penelusuran informasi menurut Kuhltau sebagai berikut (Kuhltau, 2000):

\section{Initiation}

Tahap ini terjadi saat seseorang menyadari adanya kebutuhan terhadap suatu informasi. Pada tahap ini seseorang akan mulai merenungkan dan memahami tugasnya, kemudian mengaitkan permasalahan yang dihadapi dengan pemahaman dan pengalaman yang dimiliki. Pada tahap ini perasaan seseorang masih dipenuhi ketidakpastian. Kegiatan yang dilakukan pada tahap ini dapat seperti mengobrol dengan orang lain dan melakukan pencarian informasi.

2. Selection

Pada tahap ini seseorang memiliki perasaan yang tidak pasti, tetapi mereka juga memiliki perasaan optimis karena informasi yang dikumpulkan dapat memenuhi kebutuhan, serta pola pikir yang dimiliki mulai terarah dan berupaya mempertimbangkan atau mengidentifikasi informasi yang ditemukan. Pertimbangan ini dilakukan berdasarkan berbagai kriteria, seperti ketertarikan pribadi, persyaratan tugas, ketersediaan informasi, dan waktu yang diperlukan. Pada tahap ini seseorang mulai berdiskusi dengan orang lain dan melakukan pemilihan informasi secara sistematis.

3. Eksploration

Tahap ini seseorang mulai memiliki perasaan bingung, ketidakpastian, dan keraguan seringkali yang bertambah. Keraguan dan ketidakpastian ini dapat disebabkan oleh adanya penemuan informasi yang tidak cocok, tidak konsisten dan tidak sesuai dengan konsep sebelumnya. Tindakan yang dilakukan adalah menempatkan informasi tentang topik utama, memahami dan menghubungkan informasi baru dengan apa yang telah diketahui.

4. Formulation

Pada tahap ini seseorang mulai memiliki kejelasan akan informasi yang sudah ditemukan dalam pencarian informasi. Mereka mulai melakukan tindakan yang lebih spesifik seperti membaca, membayangkan, membicarakan, dan menulis tentang tema-tema dan gagasan yang bersangkutan.

5. Collection

Pada tahap ini pencari informasi akan melakukan interaksi dengan sumbersumber informasi yang lebih banyak. Mereka mulai mengumpulkan informasi yang dapat memperjelas, memperluas bahasan informasi yang dibutuhkan dan mendukung topik kajiannya.

6. Presentation

Pada tahap ini akan muncul perasaan lega atau puas ketika pencarian informasi berjalan dengan baik dan kecewa jika terjadi sebaliknya. Pada tahap ini pencari informasi akan melengkapi pencarian dan mempersiapkan penyajian atas apa yang telah ditemukan. 


\section{b. Kajian Teori Kecemasan Penelusuran Informasi}

Setelah melakukan pencarian informasi, terkadang seseorang kembali malakukan penelusuran ulang atau mengakhiri pencarian informasi yang dilakukan. Hal ini secara lebih lanjut dikaji oleh Afifi dan Weiner dalam "Theory of Motivated Information Management" (TMIM). Teori ini membahas mengenai tahapan yang dilalui setiap individu dalam memutuskan apakah setelah mereka memiliki suatu informasi, mereka akan mencari atau menghindari melakukan pencarian informasi ulang. Menurut Afifi dan Weiner (2009) proses penentuan tersebut terbagi dalam tiga tahapan, yaitu: 1. Tahap Interpretasi, 2. Tahap Evaluasi, 3. Tahap Pengambilan Keputusan.

1. Tahap Interpretasi

Tahap pertama proses penentuan ini adalah tahap interpretasi. Pada tahap ini individu akan menilai ketidakpastian yang dimiliki tentang suatu masalah terkait informasi yang dimiliki. Individu mengalami ketidakpastian ketika merasa bahwa mereka tidak dapat memprediksi apa yang akan terjadi dalam situasi atau isu tertentu. Ketidakpastian ini disebabkan adanya kecemasan yang bermacam-macam. Kecemasan tersebut seperti ketakutan mereka yang tidak mampu memenuhi kebutuhan informasi yang beum diketahui atau ketakutan karena mereka tidak mampu untuk mengelola informasi yang lebih banyak.

Menurut Prabha, dkk (2007), kebingungan ini terjadi karena seseorang harus memilih dan menetukan mana informasi yang paling tepat dan dapat memenuhi kebutuhan mereka, dari banyaknya informasi yang mereka peroleh.

2. Tahap Evaluasi

Pada tahap evaluasi seseorang akan memutuskan apakah ia akan mencari informasi tambahan atau tidak. Hal ini karena individu memiliki kecemasan mengenai apakah informasi yang ditemukan memberikan dampak positif untuk mengurangi kecemasan mereka, atau apakah mereka mampu mengelola semakin banyaknya informasi yang ditemukan. Teori ini juga berpendapat bahwa pada tahap ini individu membuat tiga jenis penilaian keberhasilan. Tahap tersebut yaitu: coping efficacy (keberhasilan dalam mengatasi ketidakpastian), communication efficacy (keberhasilan dalam berkomunikasi) dan target efficacy (keberhasilan dalam target).

Untuk membantu para pemustaka dalam menentukan melakukan pencarian informasi yang mereka miliki, perpustakaan seharusnya dapat melakukan berbagai hal. Diantaranya seperti yang dijelaskan oleh Dempsey (2012) yaitu:

a. Pustakawan harus dapat menciptakan ruang untuk berinteraksi dengan pemustaka.

b. Perpustakaan harus turut melibatkan diri dalam bidang pendidikan dan penelitian untuk membantu kegiatan pemustaka.

c. Pada sebuah lembaga atau organisasi, perpustakaan harus dapat memposisikan diri mereka sebagai mitra lembaga induknya untuk memenuhi kebutuhan pemustaka.

d. Menyediakan fasilitas bantuan untuk memudahkan dalam kegiatan penelitian pemustaka. Seperti menyediakan subjek spesialis yang dapat dihubungi oleh pemustaka yang ingin berkonsultasi melalui kontak yang disediakan.

e. Pengelola informasi di perpustakaan harus merubah perspektif mereka dalam pengelolaan informasi yang bersifat dinamis, informasi tersebut bukan merupakan sumber informasi yang menunggu pemustaka datang menggunakannya. 
3. Tahap Pengambilan Keputusan

Setelah seorang individu membuat sebuah penilaian, tahap selanjutnya yang dilakukan yaitu memutuskan untuk melakukan hal-hal berikut: a. Melakukan pencarian informasi, b. Menghindari informasi, c. Merubah pola pikir.

Menurut TMIM, individu juga dapat mengurangi kecemasan atau ketidakpastian dengan mengubah pola pikir mereka (perubahan kognitif). Para individu dapat merubah pola pikir mengenai seberapa penting tidaknya masalah itu, tingkat keinginan mengetahui ketidakpastian yang dimiliki dan mungkin makna dari ketidakpastian itu sendiri (Afifi dan Weiner, 2009). Hal ini tentu saja dipengaruhi oleh keterampilan masingmasing individu yang berbeda-beda. Secara khusus keterampilan tersebut mencakup:

a. Kemampuan untuk mengenal kapan informasi itu diperlukan,

b. $K$ e m a m p u n u n t u k mengidentifikasi informasi yang diperlukan,

c. K e m a m p u a $\mathrm{u} n \mathrm{t} u k$ mengidentifikasi sumber-sumber informasi,

d. Kemampuan untuk menemukan serta mengakses informasi secara efisien dan efektif,

e. Kemampuan untuk mengevaluasi informasi secara kritis,

f. Kemampuan untuk mengorganisasi dan mengintegrasikan informasi dan pengetahuan yang telah dimiliki,

g. Kemampuan untuk menggunakan informasi secara etis dan legal, dan

h. Kemampuan mengkomunikasikan informasi (Darmono, 2007).

Dengan beberapa kemampuan yang dimiliki seseorang dalam kegiatan penelusuran informasi, seorang pencari informasi akan dapat menentukan bagaimana mereka mengatasi permasalahan yang dihadapi terkait dengan kecemasan dalam penelusuran informasi.

Beberapa keuntungan lain bagi seseorang yang memiliki kemampuan literasi informasi yang baik menurut Doyle yaitu (Wijetunge dan Udhita Alahakoon, 2005): a. Menentukan informasi yang akurat dan lengkap yang akan menjadi dasar dalam membuat keputusan, b. Menentukan batasan informasi yang dibutuhkan, c. Memformulasikan kebutuhan informasi, d. Mengidentifikasi sumber informasi potensial, e. Mengembangkan strategi penelusuran yang sukses, f. Mengakses informasi yang dibutuhkan secara efektif dan efisien, g. Mengevaluasi informasi, h. Mengorganisasikan informasi, i. Menggabungkan informasi yang dipilih menjadi dasar pengetahuan seseorang, $\mathrm{j}$. Menggunakan informasi secara efektif untuk mencapai tujuan tertentu.

\section{Inovasi Layanan Virtual Referens di Perpustakaan Perguruan Tinggi \\ a. Perpustakan sebagai Penyedia Informasi}

Sebagai lembaga penyedia informasi perpustakaan harus mampu menyediakan informasi yang tepat untuk membantu mengurangi kecemasan kebutuhan informasi para pemustaka. Diantara informasi yang tepat tersebut yaitu informasi yang berkualitas. Kualitas informasi yang disediakan oleh perpustakaan diantaranya dapat dilihat dari segi aksesibilitas. Lee., dkk (2002) menjelaskan bahwa dalam dimensi kualitas informasi, aksesibilitas merupakan salah satu hal yang perlu ditekankan, hal tersebut karena sebuah sistem penyimpanan informasi harus menyediakan akses pada informasi itu sendiri. Selain itu Khan (2002) menjelaskan bahwa aksesibilitas informasi dapat dilihat dari sejauh mana informasi tersedia atau dengan mudah dan cepat untuk ditemukan. 
Atas dasar ini para perpustakaan seharusnya merubah pola pikir seperti menyediakan informasi secara open access. Terutama pada perpustakaan perguruan tinggi yang identik dengan kegiatan pendidikan dan penelitian, mereka harus menyediakan informasi yang dapat diakses dari berbagai tempat untuk memenuhi kebutuhan para pemustaka. Seperti sebuah kajian yang dilakukan oleh Schonfeld (2012), yang menjelaskan mengenai peran perpustakaan akademik sebagai lembaga penyedia informasi untuk lembaga induknya, para pustakawan harus mau merubah perspektif mereka. Seperti mereka harus menyadari pentingnya keterbukaan akses informasi kepada pemustaka.

Sebagai penyedia informasi di perpustakaan, pustakawan universitas juga dapat memainkan beberapa peran untuk membantu kegiatan para pemustakanya, seperti:

\section{Librarian as Researcher, teacher and consultant}

Sebagai seorang yang ahli dalam bidang informasi, seorang pustakawan dapat berperan sebagai rekan peneliti. Hal ini agar pustakawan dapat meyediakan akses kepada sumber informasi yang tepat. Mereka dapat menjadi rekan pencarian informasi, pengelola informasi atau peringkas informasi. Oleh karena itu seorang pustakawan juga harus terampil dalam proses penelitian dan memiliki pengetahuan yang luas dan mendalam mengenai sumber informasi dalam berbagai spesialisasi subjek (Amin, dkk., 2003). Sebagai subjek spesialis pustakawan dapat memberikan layanan konsultasi penelitian kepada dosen dan mahasiswa, seperti menawarkan bantuan untuk membantu menyediakan sumbersumber informasi yang terkait dengan tema kajian mereka (Gregory, dkk., 2014).

Adapun hal lain yang dapat dilakukan oleh pustakawan dalam layanan penelitian menurut Daniel, dkk (2011) meliputi: a. Provide assistance and instruction in finding and evaluating information. $b$. Provide assistance in accessing library resources and services. c. Answer questions in person and through e-mail, phone, and instant messaging. $d$. Provide consultations for subject or other specialized areas of expertise (e.g. data services, open access, citation management). e. Document and analyze data on research transactions. O'Kelly, dkk (2015) menjelaskan, sebagai consultant librarians pustakawan juga harus memiliki beberapa kompetensi dasar seperti: a. Memiliki kemampuan dalam penelitian pada bidang keilmuan mereka dan kemampuan dalam penelitian kajian bidang lain mengenai bagaimana pemilihan sumber dan penggunaan metode. b. Mampu untuk mengajak pemustaka sebagai parter mereka agar aktif dalam mengumpulkan informasi secara.

Atas dasar ini pustakawan harus dapat memandu pemustaka dalam pengumpulan informasi, penggunaan sarana penelusuran informasi, pengorganisasian sumber daya informasi, strategi penelitian dan hal lainnya. Layanan ini tentu lebih dari kegiatan pelatihan literasi informasi, mereka harus menyediakan layanan secara lebih maju seperti membantu bagaimana mendefinisikan dan menyempurnakan topik penelitian, bagaimana menganalisis informasi yang butuhkan dan bagaimana secara kritis menafsirkan dan mengevaluasi informasi yang dihasilkan dari penelitian.

2. Librarian as Organizer and Publisher

Pustakawan juga dapat memainkan peran sebagai penyedia, evaluator dan sebuah induk dari penyedia informasi. Pada lembaga publising pustakawan dapat menjadi distributor informasi yang memberikan layanan informasi kepada klien mereka. Pustakawan harus 
dapat merubah image perpustakaan sebagai lembaga induk penyedia literatur konvensional, yang berpindah menjadi lembaga penyedia informasi yang cepat (Amin, dkk., 2003).

\section{b. Inovasi Layanan Virtual Referens}

Adanya pergeseran bentuk perpustakaan tradisional ke bentuk digital menjadikan pergeseran bentuk layanan yang diberikan oleh setiap perpustakaan. Begitu juga dalam layanan referens. Layanan yang awalnya dilakukan secara tradisional dituntut untuk diberikan secara online dan lebih inovatif. Salah satu model inovasi layanan referens yang ditawarkan yaitu virtual referens atau layanan referens online. Layanan ini dirancang untuk membantu pemustaka menggunakan teknologi, terutama ketika pemustaka tidak secara fisik datang ke perpustakaan. Seperti yang dijelaskan oleh American Library Association (2010) yang menyatakan bahwa virtual reference merupakan layanan referensi elektronik yang dilakukan oleh pemustaka menggunakan komputer atau teknologi lainnya untuk berkomunikasi dengan staf perpustakaan, tanpa hadir secara fisik.

Selain layanan virtual referens, terdapat inovasi layanan lain yang dapat disediakan oleh perpustakaan untuk membantu mengurangi kecemasan kebutuhan informasi para pemustaka. Berikut beberapa layanan inovatif yang dapat dilakukan Vohra (2007) yaitu:

1. Digital Reference Service: melalui email, web dan real time reference services seperti chatting atau instant messaging services.

2. Frequently Asked Questions: layanan jawaban dari pertanyaan yang sering diajukan pemustaka.

3. Bibliographic service/ Referral service: layanan yang menyediakan akses kepada bibliografi dan sumber web.

4. Loan and Document Delivery Service: layanan peminjaman dokumen bentuk elektronik atau dokumen konvensional yang telah diubah ke bentuk digital.
5. Current Awareness Service: informasi tentang literatur baru yang dimiliki perpustakaan terkait dengan bidang keilmuan pemustaka (Setiawan, 2016).

Bentuk-bentuk lain dari layanan layanan virtual referens yang dapat dilakukan oleh perpustakaan seperti (Kern, 2009):

1. Chat

Layanan chatting dapat dilakukan dengan menggunakan berbagai jenis media, namun karakteristik yang membedakan layanan chat pada perpustakaan dengan lainnya yaitu adanya komunikasi secara "live" (realtime atau saling terhubung).

2. Collaborative Virtual Reference

Layanan collaborative virtual reference adalah layanan referens gabungan yang dilakukan pada beberapa perpustakaan, untuk saling memudahkan para pemustaka memperoleh layanan referens secara cepat.

3. Text Messaging

Text messaging merupakan layanan referens yang memungkinkan pemustaka dengan preferensi dan perangkat elektronik yang berbeda, untuk mengirim dan menerima teks. Hal ini dapat dilakukan melalui beberapa bentuk layanan seperti Instant messsaging (IM).

4. Video conferencing or Video chat

Videochat merupakan layanan referens menggunakan transmisi video secara langsung bersamaan dengan kegiatan berpesan. Hal ini dapat dikombinasikan dengan voiP (voice-over-internet Protocol), sehingga baik gambar maupun suara dapat dikirim melalui media layanan yang digunakan seperti komputer. Sedangkan video conference dapat dilakukan dengan cara yang lebih tradisional seperti video call.

Beberapa perpustakaan universitas juga telah menyediakan berbagai inovasi terhadap layanan referens yang disediakan, terutama untuk membantu pemustaka dalam kegiatan penelitian. Diantara perpustakaan tersebut yaitu: 
1. Perpustakaan Singapore Management University. Pada perpustakaan ini menyediakan fasilitas Research Consultation dan research guide untuk para pemustaka. Fasilitas konsultasi yang disediakan sebagai berikut (Setiawan, 2016):

b. Meet your librarian, pada fasilitas ini perpustakaan menyediakan fasilitas subjek spesialis sesuai dengan tema penelitian yang dapat membantu para peneliti untuk memenuhi kebutuhan penelitiannya. Pada layanan ini pemustaka dapat membuat janji kapan mereka ingin bertemu dengan pustakawan yang dituju.

c. Research consultation dan research guide, merupakan layanan yang memberikan informasi mengenai pustakawan yang terdiri dari 40 subjek keilmuan yang berada pada SMU, yang dapat ditemui oleh pemustaka. Pada layanan research guide perpustakan juga menyediakan berbagai literatur dan sumber-sumber jurnal untuk disarankan kepada pemustaka yang mungkin diperlukan.

d. Citation and style guide, merupakan layanan yang menyediakan pedoman dan sarana untuk membuat citasi dari beberapa model. Pada fitur ini dilengkapi dengan tutorial video.

3. Perpustakaan University of Kentucky juga menyediakan fasilitas layanan referens yang menarik. Mereka memfasilitasi pemustaka untuk live chat dengan pustakawan referens, konsultasi personal dan menyediakan layanan desk referens secara online melalui email refdesk@uky.edu. Dalam hal ini mereka juga menyediakan alternatif lain seperti jika kita membutuhkan bantuan tetapi perpustakaan sedang tutup di malam hari misalnya. Fitur ini disediakan untuk para pemustaka yang membutuhkan bantuan secara cepat pada waktu-waktu tertentu saat perpustakaan tidak memungkinkan untuk membantu. Layanan tersebut yaitu ask us after dark. Fasilitas ini disediakan oleh perpustakaan agar dapat membantu para pemustaka dalam asistensi kegiatan penelitian, meskipun para pemustaka tidak bertemu dengan pustakawan secara langsung. Informasi yang tersedia pada fitur ini relatif sangat mudah untuk dipahami. Hal tersebut karena selain menyediakan informasi secara tertulis, perpustakaan juga mengemas informasi yang disediakan dalam bentuk video yang dapat mempermudah pemahaman pemustaka, khususnya para digital native yang mungkin tidak terlalu suka dengan membaca banyak tulisan (Setiawan, 2016).

4. Perpustakaan Harvard University. Perpustakaan pada universitas ini menyediakan fasilitas reserch guide. Fitur ini berisi informasi yang memberikan gambaran seperti apa jika pemustaka ingin melakukan penelitian mengenai suatu tema penelitian. Fasilitas ini akan membantu para pemustaka untuk lebih mudah memahami bagaimana cara melakukan penelitian yang baik meskipun jenis penelitian tersebut mungkin belum pernah mereka lakukan. Fasilitas reserch guide ini memberikan informasi seputar riset sesuai dengan tema penelitian para pemustaka, mulai dari proses menentukan tema penelitian, alur penelitian, hingga pengolahan data penelitian. Perpustakaan juga memberikan link pada beberapa sumber koleksi riset di tempat lain atau di perpustakaan lain yang berada di Harvard University. Pada fitur research guide juga dilengkapi fitur-fitur yang memanfaatkan media seperti video yang dapat membantu mempermudah pemahaman pemustaka. Mereka juga 
menyediakan beberapa link yang merujuk pada tools yang dapat digunakan sebagai sarana pengolahan atau pengukuran data terkait suatu tema penelitian (Setiawan, 2016).

\section{Model Layanan Virtual Referens dalam Mengatasi Kecemasan Penelusuran Informasi pemustaka}

Penulis mengadopsi model Theory of Motivated Information Management (TMIM) dengan menambahkan indikator layanan virtual referens yang berperan untuk membantu pengambilan keputusan dan efficacy (keyakinan) pemustaka dalam menentukan apakah mereka akan melakukan penelusuran informasi atau tidak.

Gambar tersebut menjelaskan tahap yang dilalui individu sebelum melakukan kegiatan penelusuran informasi. Tahap ini menurut Afifi dan Weiner (2009) terbagi dalam tiga tahap yaitu: tahap interpretasi dimana seseorang akan melakukan penilaian antara kebutuhan informasi yang dimiliki dan kecemasan yang dirasakan dalam proses penelusuran informasi. Kecemasan ini terkait dengan kekhawatiran dan kemampuan masing-masing individu dalam menemukan dan mengelola sumbersumber informasi. Hal ini akan menimbulkan emosi dalam diri individu yang akhirnya mempengaruhi proses selanjutnya pada tahap evaluasi. Pada tahap evaluasi, individu akan menilai seberapa besar keyakinan melakukan penelusuran informasi berdasarkan kemampuan masingmasing individu. Pada tahap emosi dan efficacy yang dimiliki individu selanjutnya akan mempengaruhi pengambilan keputusan dalam menentukan apakah individu akan melakukan pencarian informasi, menghindari pencarian informasi, atau bahkan merubah pola pikir mereka mengenai kebutuhan informasi yang dimiliki (Afifi dan Weiner, 2009). Pada model ini penulis menambahkan indikator layanan virtual referens yang mempengaruhi kepercayaan individu dan pengambilan keputusan dalam pencarian informasi. Model dari penulis sebagai berikut:

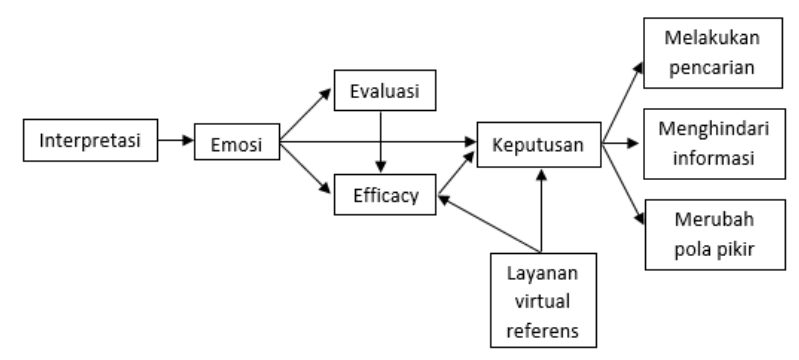

\section{E. KESIMPULAN}

Adanya perbedaan kemampuan masingmasing individu dalam penelusuran informasi, menimbulkan kecemasan mengenai apakah mereka dapat menemukan dan mengelola informasi sesuai kebutuhan. Untuk mengatasi permasalahan ini perpustakaan dapat melakukan beberapa inovasi layanan yang disediakan kepada pemustaka. Diantaranya yaitu dengan menyediakan layanan virtual referens. Bentuk layanan virtual referens yang dapat dilakukan seperti: layanan research consultation yang dilakukan pada perpustakaan Singapore Management University, live chat dan penyediaan informasi dalam bentuk video yang dilakukan perpustakaan University of Kentucky, research guide yang dilakukan perpustakaan Harvard University, layanan ask librarian, layanan research assistant dan sebagainya. Tersedianya inovasi layanan virtual referens, diharapkan dapat mempengaruhi kepercayaan diri seorang pemustaka dalam proses penelusuran informasi yang dibutuhkan. 


\section{DAFTAR PUSTAKA}

Afifi, W. \& Weiner, J. (2009). Motivated Information Management Theory. Encyclopedia Of Communication Theory. Thousand Oaks: Sage Publication.

American Library Association. (2010). Guidelines for Implementing and Maintaining Virtual Reference Services. Diunduh dari: www.nlai.ir/portals/0/pdf/ 2a.pdf. Pada 23 November 2016.

Amin, Adida Mohd., dkk. (2003). Role and Function of Information Professionals in Digital Libraries. Kekal Abadi, Vol. 22, No. 2, pp. 7-13.

Ati, Sri., dkk. (2013). Dasar-Dasar Informasi. Tangerang Selatan: Universitas Terbuka.

BSNI. (2009). Perpustakaan Perguruan Tinggi. Jakarta: Badan Standar Nasional Indonesia.

Daniel, Linda., dkk. (2011). Engaging With Library Users: Sharpening Our Vision as Subject Librarians for The Duke University L i b r a ries. Di und u h a ri : https://library.duke.edu/.../subjectlibrarian-report-2011.pdf. Pada 23 November 2016.

Darmono. (2007). Perpustakaan Sekolah. Jakarta: PT Grasindo.

Dempsey, Lorcan. (2012). Libraries and the Informational Future: some notes Information Professionals 2050: Educational Possibilities and Pathways. Diunduh dari: https://pdfs . semanticscholar.org/5568/a103732d611e6d c28f3d92c0e2e08dc8f890.pdf. Pada 23 November 2016.

Erfanmanesh, Mohammadamin. (2016). Information Seeking Anxiety: Effects of Gender, Level of Study and Age. Diunduh dari: http://digitalcommons.unl.edu/ libphilprac/1317. Pada 23 November 2016.

Ghony, M. Djunaedi dan Fauzan Almanshur. (2012). Metodologi Penelitian Kualitatif. Jakarta: Ar-Ruzz Media.

Gregory, Patricia., dkk. (2014). Subject Librarian Contributions to Student Learning and Success. Diunduh dari: http://lib.slu.edu/files/about/subjectlibrarian-contributions-to-student-learningand-success.pdf. Pada 23 November 2016.
Kern, M. Kathleen. (2009). Virtual reference best practices: tailoring ser vices to your library. Kansas: American Library Association.

Khan, Beverly K. (2002). Information Quality Benchmarks: Product and Service Performance, Communications of the ACM, Vol 45, No. 4, pp. 184-192.

Kuhltau. (2000). The Information Search Process (ISP). Diunduh dari: http://comminfo.rutgers.edu/ kuhlthau/ information search process.htm. Pada 22 November 2016.

Lee, Y.W.dkk. (2002). AIMQ: A Methodology for Information Quality Assessment. Information \& Management, Vol. 40, No. 2, pp 133-146.

O'Kelly, Mary., dkk. (2015). Building a PeerLearning Service for Students in an Academic Library. Libraries and the Academy, Vol. 15, No. 1, pp. 163-182.

Orlu, Aondoana Daniel. (2016). "Information Seeking Behaviour of Masters Students: Affective and Behavioural Dimensions". Diunduh dari: http://digitalcommons. unl.edu/libphilprac/1387. Pada 23 November 2016.

Pendit, Putu Laxman. (2008). Informasi: Dibutuhkan, Diinginkan, Diperlukan. Diunduh dari: http://iperpin. wordpress.com/2008/10/11/informasidibutuhkan-diinginkan-diperlukan/? blogsub=confirming\#subscribe-blog. Pada 22 November 2016.

Prabha, Chandra., dkk. (2007). What is Enough? Satisficing Information Needs. Journal of Documentation, Vol. 63, No. 1, pp. 74-89.

Schonfeld, Roger. (2012). Information Professionals to Serve Academia. Information Professionals 2050: Educational Possibilities and Pathways. Information Service \& Use, Vol. 32, No. 3-4, pp. 227-229. 
Setiawan, Moh Very. (2016). Inovasi Layanan Refrensi pada Perpustakaan Peguruan Tinggi Sebagai Penunjang Kegiatan Penelitian Civitas Akademika. Prosiding Seminar SLiMS Commeet West Java 2016. Kreativitas Pustakawan pada Era digital dalam Menyediakan Sumber Informasi bagi Generasi Digital Native. Bandung: Unpad Press.

Sulistyo-Basuki. (2010). Metode Penelitian. Jakarta: Penaku.

Vohra, Neeru Bhatia Ranjana. (2007). Trends in Reference and Information Services in The Electronic Era: A Case Study of AC Joshi L i b a r y. D i u $\mathrm{n} \mathrm{u} \mathrm{h} \mathrm{d} \mathrm{a} \mathrm{r} \mathrm{i} \mathrm{:}$ http://ir.inflibnet.ac.in/bitstream/1944/1437 /1/617-630.pdf. Pada 23 November 2016.
Wijetunge, P dan Udhita Alahakoon. (2005). Empowering 8: The Information Literacy Model Developed in Srilanka to Underpin Cahanging Education Pradigms of Sri Lanka. Diunduh dari: www.cmb.ac.lk/ academic/institute/nilis/reports/iformationli teracy.pdf. Pada 22 November 2016.

Yusuf, Pawit M dan Priyo Subakti. (2010). Teori dan Praktik Penelusuran Informasi: Information Retrival. Jakarta: Kencana. 